\title{
21 RITUAL SLAUGHTER AND RELIGIOUS FREEDOM: THE IMPACT ON THE FLOURISHING OF RELIGIOUS COMMUNITIES IN SOUTH AFRICA
}

\section{Helena van Coller ${ }^{1}$}

\section{INTRODUCTION}

The slaughter of animals as part of cultural and religious practice is a global phenomenon and highlights the difficult boundaries to be drawn between the rights to freedom of religion, on the one hand, and other rights, such as animal rights, on the other. Early in 2007, South African African National Congress (ANC) heavyweight Tony Yengeni slaughtered a bull at his father's house in Gugulethu as part of a cleansing ceremony following his release from prison. There was public outcry and animal rights activists objected to the slaughter because the practice constituted cruelty to animals. ${ }^{2}$ The recent arrest of a South African pastor on charges of animal cruelty for feeding live snakes to his congregation also highlights these difficult issues and the need for further debate and discussions. ${ }^{3}$ In accordance with the religious practices of Judaism and Islam, the animal must be conscious when killed, for meat to be considered kosher under Jewish law or halal under Islamic law. However, legislation in various other countries requires animals to be stunned before they are slaughtered, rendering the animal unconscious.

Discrimination in relation to Jewish and Islamic practices is more often found on the European front and decided and challenged in terms of European Convention on Human Rights (ECHR) law. Both on a European level and in terms of the domestic law of many European countries, prescriptions of stunning are dealt with as a matter of animal welfare. Legislation is then often aimed at the health and welfare for animals, so that in the name of humanity all animals have to be stunned before being slaughtered. Although certain legislation in South Africa, such as the Meat Safety Act No. 40 of 2000, does provide for slaughter practices for the religious purposes of the Muslim faith, most slaughter practices are performed in terms of the religious customs and practices of African tradition religions (ATR), which are the focus of this discussion.

Religious communities and their leaders argue that churches and religious organisations are already "over-regulated" and that this can create the danger of

1 Associate Professor, Faculty of Law, Rhodes University, South Africa.

2 See various media reports: Mantsho M. 2011. "Rights Commission: Animal Slaughter should continue", Mail \& Guardian, 29 March; Unknown. 2007. "Bull Brand for Tony Yengeni", Sowetan Live, 23 January; Sapa. 2007. "Yengeni Bull Slaughter Defended", IOL News, 25 January.

3 See also De Vos P. 2015. "Not All Animals are Equal Under South Africa Law”, Daily Maverick, 22 July; Patel F. 2015. "SPCA Investigates Snake Pastor", Eyewitness News, 17 July. 
violating communities' rights to freedom of religion. This can further lead not only to conflict within religious communities, but also to an increase in religious disputes that end up in court. This ultimately has an effect on how communities flourish and influence communities' human well-being. This chapter will briefly address the issue of government regulation of religion in the context of ritual slaughter and the question of what impact this can have on the human flourishing of religious communities. For religious communities to flourish, it is important for them to be able to enjoy and practise their religion and the state must create a positive environment and respect, protect, promote and fulfil the Bill of Rights, including the right to freedom of religion. However, no right is absolute and even the right to freedom of religion must be enjoyed in a manner that is conscious of the rights of others. The Commission for the Promotion and Protection of the Rights of Cultural, Religious and Linguistic Communities (CRL Rights Commission) ${ }^{4}$ has recommended that municipalities should look at amending bylaws to allow communities to slaughter animals for religious and cultural reasons, but at the same time, they must ensure the welfare of the animals. The chapter will outline some important concepts for purposes of the discussion. With reference to some examples, the discussion will then analyse the limitation of the various rights and outline the applicable legislative framework. It draws a short conclusion at the end, indicating that it is constitutionally permitted to limit the practice of religious slaughter through legislation and other means, whilst still giving due regard to communities' right to practise their religion.

\section{THE MEANING OF "RELIGIOUS SLAUGHTER" AND "RELIGION"}

Religious pluralism pre-supposes various definitions and interpretations of "religion", and as one scholar has observed "the scope of religious pluralism ... alone has resulted in such a multiplicity and diversity of ideas about what is a 'religion' or a 'religious belief' that no simple formula seems able to accommodate them all". ${ }^{5}$ In accordance with the South African Declaration on Religious Rights and Responsibilities, a religious community is described as "a group of people who

4 Section 181(1)(b) of the Constitution of the Republic of South Africa, 1996, constitutionally mandates and empowers the CRL Rights Commission, which is independent from the government and subject only to the Constitution and the law. In terms of Section 181(2) of the Constitution, state institutions supporting democracy, of which the CRL Rights Commission is one, "must be impartial and must exercise their powers and perform their functions without fear, favour or prejudice". Section 185 of the Constitution sets out the functions of the CRL Rights Commission, including the promotion of respect for the rights of cultural, religious and linguistic communities, and to develop peace, friendship, humanity, tolerance and national unity amongst cultural, religious and linguistic communities on the basis of equality, non-discrimination and free association. The Commission for the Promotion and Protection of The Rights of Cultural, Religious and Linguistic Communities Act 19 of 2002 (CRL Act) was enacted to give effect to Section 185.

5 Quoted from Labuschagne JMT. 1997. “Die Begrip 'Godsdiens' in Godsdiensvryheid: 'n Bewussynsantropologiese Ekskursie na die Evolusiekern van die Reg" [The Concept 
follow a particular system of belief, morality and worship, either in recognition of a divine being, or in the pursuit of spiritual development, or in the expression of a sense of belonging through social custom and ritual" ${ }^{6}$

The meaning of "religion" is also important for purposes of the collective right to freedom of religion in determining when an organisation will be treated as "religious" in order to qualify for the protection afforded by the Constitution of the Republic of South Africa. For reasons of practicality and to empower the courts to efficiently deal with religious disputes, European Union constitutional law scholar Gerhard van der Schyff rightly proposes a functional approach, rather than a purely philosophical or theological approach. ${ }^{7}$ In a legal context, this functional approach will be followed throughout the discussion in terms of how a religious institution will be defined and qualified in accordance with certain qualities and characteristics.

According to Van der Schyff's functional approach, at least the following characteristics must be present in order to qualify as "religion": a belief in a supreme being, a belief in a transcendental reality, a moral code, a worldly view that describes the human role in the universe and in terms of which an individual organises and manages his life, holy rituals and festivals, worship and prayers, holy scriptures and texts, and the existence of a social organisation that supports and develops the said belief system. ${ }^{8}$ Although authors may disagree with each other on the exact meaning of "religion" - I think most agree on the importance of religion in society. As correctly pointed out by the German theologian Rudolf Otto, "religion is as much a matter of fact as the reality of humanity itself". ${ }^{9}$ Similarly, in the case of Christian Education South Africa v Minister of Education, Justice Albie Sachs stated: "Religion is not just a question of belief or doctrine. It is part of a way of life, of a people's temper and culture." 10

In the context of this chapter's topic of religious animal slaughter, the question that comes to mind is what exactly is "religious slaughter", and does it form part of

of Religion in Religious Freedom: An Awareness Anthropological Excursion to the Evolutionary Core of Law], De Jure Law Journal 118-119.

6 A South African Declaration on Religious Rights and Responsibilities, accepted and assented to during the National Inter-religious Conference, held in November 1992, under the auspices of the South African Chapter of the World Conference on Religion and Peace (WCRP-SA). See also Du Plessis LM. 2001. "Current Problems Concerning Church and State Relationships and Religious Freedom in South Africa: The Viewpoint of a Constitutional Lawyer", in Warnink H (ed). Legal Position of Churches and Church Autonomy. Leuven: Peeters, $15 \mathrm{ff}$.

7 Van der Schyff G. 2002. "The Legal Definition of Religion and its Application", South African Law Journal 119:289.

8 Van der Schyff, “The Legal Definition of Religion and its Application”, 290.

9 Otto R. 1917. Das Schaudern ist der Menschheit bestes Teil. Wie auch die Welt ihm das Gefiihl verteuere, Ergriffen fiihlt er tief das Ungeheuere. [The Idea of the Holy: An Inquiry into the Non-rational Factor in the Idea of the Divine and its Relation to the Rational] [1923] (translated by Harvey JW). London: H Milford/Oxford University Press, 154.

10 Christian Education South Africa v Minister of Education 2000 (4) SA 757 (CC), para 33. 
"religion"? Religious slaughter is the slaughter of animals in accordance with certain religious beliefs and practices. As Dutch legal scholar Gerhard van der Schyff explains:

Religious slaughter can generally be understood as the process whereby an animal, usually a warm-blooded vertebrate, is slaughtered according to the requirements of a particular religious faith. Adhering to religious tenets during the act of slaughter is thus a key component of ritual slaughter, which clarifies why the practice is also referred to as religious slaughter. ${ }^{11}$

For followers of a particular faith, this practice may be a binding requirement, and where meat has not been ritually slaughtered, communities may reject it for not having been religiously sanctioned. In African traditional religions, the religious slaughter is not only a religious act itself, but also a communal practice used during religious festivals. Often the meat is eaten after its sacrifice.

Two prominent religions, particularly in Europe, where religious slaughter is of great importance, are Judaism and Islam. In Judaism, the practice of religious slaughter is known as shechita and in Islam as dhabiha. Meat that conforms to the Jewish dietary laws is referred to as kosher and halal if in accordance with Islamic requirements. For animal slaughter to be lawful under Jewish law and sharia (Islamic) law, Jewish and Muslim conditions have to be met before an animal is cut and bled. In both religions, the animal must be alive when these procedures are carried out, and animals may not be stunned before they are slaughtered. A certified practitioner must carry out the ritual and the animal must bleed to death. ${ }^{12}$ The welfare of animals is very important in both religions. Animals should not experience any pain or be subjected to unnecessary suffering. However, there is no uniform approach of what is acceptable or not within these religions, and in some countries the stunning of animals prior to the killing of the animal is the norm for many religious groups. In Denmark, for instance, the stunning of animals before slaughter has been accepted by many Muslims since 2004, when the last slaughterhouse willing to forgo stunning before slaughter closed down. Many Muslims are of the view that as long as the concussion is not the cause of death of the animal, the animals stunned before slaughter are still considered halal. Although a majority of the Muslim community accepts this view, the Jewish community and those with similar concerns, have instead opted for imported meat. ${ }^{13}$ The religious rules applicable to food is seen as "deeply symbolic" and an expression of a relationship between the believer and God. Complying with these rules is a way in which "the faithful are reminded of the presence of the significant in the common place" and it "affects the moral and spiritual character of the individual, which ultimately determines his wellbeing and salvation". ${ }^{14}$

11 Van der Schyff G. 2014. "Ritual Slaughter and Religious Freedom in a Multilevel Europe: The Wider Importance of the Dutch Case", Oxford Journal of Law and Religion 3(1):77.

12 Van der Schyff, "Ritual Slaughter and Religious Freedom in a Multilevel Europe", 78.

13 Overgaard S. 2014. "Banning Traditional Animal Slaughter, Denmark Stokes Religous Ire", National Public Radio, 9 April.

14 Kroeze IJ. 2012. "How to Eat: Vegetarianism, Religion and Law", The Journal for Transdisciplinary Research in Southern Africa 8(1):5. 
In Africa, particularly South Africa, African traditional religions (ATR) are very prominent. There is no universally agreed upon definition of ATR, although authors agree on certain shared features, such as the belief in a supreme being, divinities, spirits, ancestors, and the practice of magic and medicine. ${ }^{15}$ According to the African religious scholar, John Mbiti, ATR was for believers "the normal way of looking at the world and experiencing life itself". ${ }^{16}$ Emphasis is placed on the daily experience of the person in such a manner that the African spiritual experience is described as on in which the "divine ... interpenetrates into the daily experience of the human person so much that religion, culture, and society are imperatively interrelated". ${ }^{17}$ For purposes of this discussion, important aspects of ATR include the belief in ancestral spirits, according to certain set rituals and practices "the correct observance of these rituals" is an important feature of indigenous African beliefs. ${ }^{18}$ Nokuzola Mndende, an African indigenous religion practitioner and scholar, describes rituals as "extraordinary practices performed by the living for the spiritual world". ${ }^{19}$ As Mndende explains:

Rituals are special gatherings of the clans aimed at communal religious practices. These are communal religious practices for some special purposes like the rites of passage, thanksgiving, divination rituals, and sometimes special rituals as requested by ancestors, like the bringing back of the spirit of some family member who died far away from home. In these religious gatherings, the community acts out its various forms of worship. Through these rituals, unity and healing are achieved. ${ }^{20}$

In ATR, the focus is also much more on the communal nature of the practice, and in the traditional African society "religious beliefs stand at the centre of life". ${ }^{21}$ During ritual performances, the members come together and perform the ritual as a collective. ${ }^{22}$

An interesting example of a ritual bull killing came before the courts in Smit $v$ King Goodwill Zwelithini. ${ }^{23}$ In Smit, the Zulu King, Goodwill Zwelithini, decided to revive

15 Nyaundi NM. 2011. "African Traditional Religion in Pluralistic Africa: a Case of Relevance, Resilience and Pragmatism", in Bennett T (ed). Traditional African Religions in South Africa. Cape Town: UCT Press, 6.

Mbiti JS. 1975. Introduction to African Religion. London: Heinemann Educational Publishers, 12-17.

17 Masonda S. 2011. “The Practice of African Traditional Religion in Contemporary South Africa", in Bennett T (ed). Traditional African Religions in South Africa. Cape Town: UCT Press, 20. Masonda, "The Practice of African Traditional Religion".

19 Mndende N. 2013. "Law and Religion in South Africa: An African Traditional Perspective", Nederduitse Gereformeerde Teologiese Tydskrif 54(4):78.

20 Mndende, "Law and Religion in South Africa", 78.

21 Mndende, "Law and Religion in South Africa", 78.

22 Mndende, "Law and Religion in South Africa", 78.

23 Smit NO and Others $v$ King Goodwill Zwelithini Kabhekuzulu and Others (10237/2009) [2009] ZAKZPHC 75 (4 December 2009). 
the First Fruits Festival (also called the Umkhosi Ukweshwama) with the ritual of bull slaughtering. Animal activists were outraged, and the Animals Rights Africa Trust approached the court for an interdict to try to prevent the slaughtering of the bull. The ceremony has been described as "an annual event that takes place at around the same time each year for significant religious and cultural reasons". ${ }^{24}$

In ATR, it is often very difficult to separate the religious aspects from the overriding culture. As legal scholar Jewel Amoah has described it, "The line between religion and culture is a blurred and grey one. Yet, despite the melting of into the other, religion and culture exist as distinct entities, providing substantive content and character both to individuals and communities. The blurred line results in a tendency to mistake one for the other, or to conflate one with the other ... In reality, it is often very difficult to distinquish African religion from African culture' ${ }^{25}$ Even so, there seems to be a tendency amongst scholars to treat religious rights as more important than cultural rights. In relation to ritual slaughter, Amoah and her colleague Tom Bennett, are of the view that "it seems that those working under the influence of modern human rights take religion more seriously than culture" and that the same measure of deference exercised by the courts in relation to religious practices are not exercised in the same manner in relation to cultural practices. ${ }^{26}$ This tendency to privilege religion can also be seen in relation to various rituals within the ATR, such as marriage, rites of passage, funerals, circumcision - all rituals seen in other religions as religious in nature, but which in terms of ATR are seen as cultural practices. In Smit, the community itself saw no need to make a distinction between the two, and thus the court described the festival as both a "religious and cultural event". ${ }^{27}$

For purposes of protection of the right to freedom of religion in Section 15 of the South African Constitution, it is important to determine whether the ritual bull slaughter can, indeed, be classified as religion. Applying some of the definitions and characteristics of religion outlined above, it is difficult not to classify this Zulu tradition as religious in nature. According to Christa Rautenbach, a constitutional law scholar, "there is enough empirical evidence to prove that Zulus believe their traditions, including the Festival, to be religious". ${ }^{28}$ Rautenbach further argues that the "primary phenomenon of religion is ritual. Ritual is religion in action ...

24 Smit v King Goodwill Zwelithini, para 9.

25 Amoah J. 2011. "Religion vs Culture: Striking the Right Balance in the Context of African Traditional Religions in the New South Africa", in Bennett T (ed). Traditional African Religions in South Africa. Cape Town: UCT Press, 61.

26 Amoah J and Bennett T. 2008. "The Freedoms of Religion and Culture under the South African Constitition: Do Traditional African Religions Enjoy Equal Treatment?", African Human Rights Law Journal 8:368. Smit v King Goodwill Zwelithini, para 9.

28 Rautenbach C. 2011. “Umkhosi Ukweshwama: Revival of a Zulu Festival in Celebration of the Universe's Rites of Passage", in Bennett T (ed). Traditional African Religions in South Africa, 74 . 
Belief, although its recitation may be part of the ritual, or a ritual in its own rights, serves to explain, to rationalise, to interpret and direct the energy of the ritual performance ... It is ritual which accomplishes what religion sets out to do." ${ }^{29}$ It can, thus, be argued that the Zulu tradition was indeed a religious ritual, which should qualify for constitutional protection.

The court in Smit found the facts presented by the two parties to be in dispute based on different versions of the slaughter practice presented to the court. Due to the factual dispute between the parties, the court dismissed the application. The Ukweshwama ceremony was allowed to go ahead. The court was also of the view that "the slaughter of the bull and the manner in which it is done, is to approach the relevant authorities with the view of resolving the conflict between the Applicant and the representatives of the ZULU nation. Hopefully Parliament would intervene with a view to put this issue to rest." 30 The court declined to resolve or discuss the religious debate further.

The inhumane treatment of animals is but one of the issues raised by animal activists in relation to animal slaughter. Often animals are transported thousands of kilometres for ritual and informal slaughter. They are transported in unsuitable vehicles and often abused by being immobilised with cruel cutting methods. The slaughter practices are not monitored, and those performing the slaughter practices often have no or very little experience. ${ }^{31}$ This raises the question whether the practice of religious slaughter as a component of the right to freedom of religion can justifiably be limited and what the legislative framework would be for the protection, but also the regulation of these practices. The next discussion will briefly discuss the limitation of rights and the applicable legislative framework.

\section{LIMITATION OF RIGHTS}

Section 15 of the Constitution of the Republic of South Africa provides for very wide protection of religious freedom by stating that everyone has the right to freedom of conscience, religion, thought, belief and opinion. The right to believe always goes hand in hand with the right to manifest and practise those beliefs, which means that one has the right to the private or public, and the individual or joint, observance and exercise of one's religious or other convictions. Religious activities, such as the slaughtering of animals, are ways in which believers manifest and practise their beliefs. These practices form part of the right to freedom of religion,

29 Rautenbach, "Umkhosi Ukweshwama”, 75.

30 Smit v King Goodwill Zwelithini, para 18.

31 Useful and up to date information on animal cruelty in South Africa can be found on the website of the National Council of the Society for the Prevention of Cruelty to Animals (SPCA) at https://nspca.co.za/ and the websites of the various local branches of the SPCA. The SPCA is the only animal welfare organisation in South Africa regulated by an Act of Parliament (SPCA Act of 1993). Their mission is to prevent cruelty and promote the welfare of all animals. Material on animal welfare and useful information on how to report incidents of animal cruelty are also available on their website. 
protected under Section 15 of the Constitution, which, when read together with Section 31, guarantees the right to persons belonging to religious communities, to enjoy and practise their religion with other members of that community. This is further entrenched in Section 4 of the South African Charter of Religious Rights and Freedoms (SACRRF), which states that "every person has the right to the private or public, and individual or joint, observance or exercise of their convictions, which may include but are not limited to reading and discussion of sacred texts, confession, proclamation, worship, prayer, witness, arrangements, attire, appearance, diet, customs, rituals and pilgrimages, and the observance of religious and other sacred days of rest, festivals and ceremonies". ${ }^{32}$

However, no fundamental right is absolute, and even the right to freedom of religion can be justifiably limited in accordance with the South African Constitution to the extent that the limitation is reasonable and justifiable in an open and democratic society based on human dignity, equality and freedom. The limitation and regulation of these practices may be necessary in order to preserve peace and tranquillity, particularly in localities where people of different faiths reside. As pointed out by Justice Sachs in the case of Christian Education South Africa: ${ }^{33}$

The underlying problem in any open and democratic society based on human dignity, equality and freedom in which conscientious and religious freedom has to be regarded with appropriate seriousness, is how far such democracy can and must go in allowing members of religious communities to define for themselves which laws they will obey and which not. Such a society can cohere only if all its participants accept that certain basic norms and standards are binding. Accordingly, believers cannot claim an automatic right to be exempted by their beliefs from the laws of the land. At the same time, the state should, wherever reasonably possible, seek to avoid putting believers to extremely painful and intensely burdensome choices of either being true to their faith or else respectful of the law. The right of religious communities to believe and to be able to manifest and practise those beliefs by members is important. However, the reasonable regulation of religious practices through legislation is a justifiable way of limiting the practices in terms of the law of general application.

Based on the doctrine of non-entanglement in doctrinal issues, as applied in South Africa, the state is prohibited from interfering with religious organisations and

32 The South African Charter of Religious Rights and Freedoms, 1996, is a document that defines the freedoms, rights, responsibilities and relationship between the state and religious believers in South Africa. The Charter was first signed at a public ceremony in Johannesburg on 21 October 2010, and signatories continue to be added to the open document. Signatories include religious groups and organisations, human rights organisations, legal and academic entities and media bodies. The Charter has not been passed into law, but it may be used as a legal instrument guiding the relationship between the state and its citizens in relation to religion and promoting understanding and tolerance between government and religion in South Africa.

33 Christian Education South Africa v Minister of Education 20004 SA 757 (CC); 200010 BCLR 1050 (CC), para 35. 
churches' autonomous sphere. Under the South African Constitution, religious organisations enjoy a sphere of autonomy concerning religious doctrine, and actions and procedures flowing from them. Read together with the right to freedom of association (Section 18) and the rights of religious communities (Section 31), the right to freedom of religion further guarantees a degree of autonomy for religious communities to manifest their beliefs and run their affairs without interference. The South African Charter of Religious Rights and Freedoms further guarantees every religious institution the right to institutional freedom of religion, including the right to determine its own doctrines, and to regulate its own internal affairs, including organisational structures and procedures. Every religious institution is recognised and protected as having authority over its own affairs, and the State, including the judiciary, must respect the authority of every religious institution over its own affairs, and may not regulate or prescribe matters of doctrine and ordinances. The term "management of own religious affairs", can be interpreted in many ways. According to Krishnaswami, it refers to matters that fall within the dogma of a religious institution and matters that pertain to faith, ritual and doctrine. This can include the organisational structure of an institution, its membership and spiritual administration. Government legislation determines the scope of religious freedom for individuals as well as the collective autonomy of religious organisations. Through various duties, prohibitions and conditions, the state can regulate religion by setting limits to the exercise of religious organisation's rights. Our courts have emphasised that the issues that went to sensitive matters of church doctrine and governance were issues "that the Church should be left to determine domestically, as far as is possible, without interference from the Court. The Court should only become involved in the dispute where it is strictly necessary to do so. Even then, I am advised and submit that it will refrain from determining doctrinal issues, in order to avoid religious entanglement. ${ }^{34}$

Therefore, as carriers of the right to freedom of religion, religious institutions have the autonomy to implement their own religious doctrines and beliefs. Section $7(2)$ of the South African Constitution also emphasises that the state must not only fulfil the Bill of Rights, but must also protect and promote these rights and create a space in which the right to freedom of religion, both individual and collective, can be exercised. As pointed out above, the right to freedom of religion, including the practice of religious slaughter, can be limited in accordance with Section 36 of the Constitution, the limitation clause, in terms of a law of general application, if the limitation is reasonable and justifiable in an open and democratic society. In order to determine whether the limitation is reasonable and justifiable, factors including the nature of the right, the importance of the purpose of the right, the nature and extent of the limitation, the relation between the limitation and its purpose and whether there are less restrictive means to achieve the purpose must all be considered. I will discuss these factors briefly.

34 De Lange v Presiding Bishop, Methodist Church of Southern Africa 2015 (1) SA 106 (SCA), para 30. 


\section{The nature of the right}

There is no doubt that the right to freedom of religion is a very important right, as highlighted above, with reference to the case of Christian Education South Africa. ${ }^{35}$ As the court stated in that case:

There can be no doubt that the right to freedom of religion, belief and opinion in the open and democratic society contemplated by the Constitution is important. The right to believe or not to believe, and to act or not to act according to his or her beliefs or non-beliefs, is one of the key ingredients of any person's dignity. ${ }^{36}$

The right is also entrenched in Sections 15 and 31 of the South African Constitution and Section 4 of the South African Charter of Religious Rights and Freedoms. In relation to the nature of the right, religious slaughter as a manifestation of the right of freedom of religion is an extremely important right in South Africa and should only be limited in exceptional circumstances and where the limitation is of great importance.

\section{The importance of the purpose of the right}

The second factor relates to the importance of the purpose of the limitation. In order to be reasonable, the limitation must at a minimum serve some legitimate purpose, one that is important in a democratic democracy. Thus, the limitation must advance an important state interest. A legitimate purpose can include the prevention of harmful practices or protecting the rights of others, or advancing the general well-being of the community. A legitimate state interest in this particular case can be to protect citizens from abusive practices, public health and safety and the promotion of animal welfare.

The court in MEC for Education: Kwazulu-Natal and Others v Pillay made it clear that even the "most vital practice of a religion or culture can be limited for the greater good. No belief is absolute, but those that are closer to the core of an individual's identity require a greater justification to limit". ${ }^{37}$ In appropriate circumstances, the practice of religious slaughter can be limited or at least regulated in order to ensure the welfare of animals. As discussed in the next section, legislation aimed at the prevention of cruelty to animals and setting national standards in relation to abattoirs include the Meat Safety Act No. 40 of 2000 and the Animals Protection Act No. 71 of 1962, read with various municipal bylaws. 


\section{The nature and extent of the limitation}

The observance of religious practices and rituals is an integral part of the indigenous African beliefs. Religious slaughter is a way in which believers manifest and practise their beliefs. This factor requires the court to assess the way in which the limitation on ritual slaughter affects the right concerned, in that the infringement of rights (the right to manifest a belief) should not be more extensive than is warranted by the purpose (animal welfare, public health and safety) that the limitation seeks to achieve. Any law that seeks to limit a right should not use a sledgehammer to crack a nut. ${ }^{38}$ It is thus important to assess how extensive the infringement is. A total prohibition on this practice may be said to be too severe and will constitute a violation of communities' right to freedom of religion and will have a significant impact on religious communities. However, a reasonable limitation of the right by imposing certain restrictions and set out guidelines through legislation, may be said to be reasonable.

\section{The relation between the limitation and its purpose}

In relation to the link between the limitation and its purpose, the question is whether the severity of the limitation on the practice of religious slaughter outweigh the importance and purpose of the limitation. In order for the limitation to be reasonable and justifiable in an open and democratic society, it must be proportionate to the benefit. Section 2 of the Animals Protection Acts provides that any person who causes unnecessary suffering to an animal shall be guilty of an offence and liable on conviction to a fine or to imprisonment in accordance with its provisions. With reference to the Zulu Ukweshwama slaughter ceremony highlighted above, legal scholar Sarah Smith, argues that this limitation in terms of the Animals Protection Act will have a considerable impact on the Zulu nation and that "[t]he negative impact of the limitation is disproportionate to the (undefined) benefit of protecting human sentiments, as intended by the legislation" ${ }^{39} \mathrm{~A}$ total prohibition on any form of religious slaughter, rather than a justifiable limitation in the form of regulation, can be regarded as disproportionate, particularly since the last factor requires that less restrictive means to achieve the purpose should be considered.

\section{The question whether there are less restrictive means to achieve the purpose}

The last requirement considers whether there are less restrictive means or alternative methods that can be used to achieve the same purpose. The justifiable regulation of the practice through legislation and municipal bylaws (rather than a total ban or to criminalise the practice) can be an alternative method of achieving the purpose. This would be a reasonable and justifiable way of limiting the practice

38 See S Manamela 2000 (3) SA 1 (CC), para 34. 
of religious slaughter as a manifestation of the right to freedom of religion in terms of law of general application. Christa Rautenbach maintains, "Although a court is not empowered to pronounce upon the truth or credibility of religion, constitutional limitations aimed at the achievement of a desirable social result may be placed on religious rituals. It is not desirability of the ritual that is evaluated but the desirability of its effect, and one has to agree that it is the responsibility of government to give direction in the form of policy and legislation when dealing with these issues." 40

\section{LEGISLATIVE FRAMEWORK}

The factors described in the section above are considerations in the application of the relevant national and municipal including the Meat Safety Act No. 40 of 2000, the Animals Protection Act No. 71 of 1962 and various municipal bylaws. The law confers no legal rights upon animals and in terms of our common law, animals are regarded as corporeal property, which may be used at the discretion of the owner, free from any legally recognised right to life or to humane treatment or use. Legislation aimed at prohibiting cruelty to animals are ordinarily phrased not to interfere with the reasonable exercise of property rights and often only prohibit the infliction of pain and suffering which is unnecessary or unreasonable. Where an act thus causes pain or suffering which is not reasonable or necessary in the circumstances, it will be regarded as cruel. ${ }^{41}$

The Animal Protection Act No. 71 of 1962, repealed the Prevention of Cruelty to Animals Act No. 8 of 1914, under which many casee involving acts of animal cruelty have been decided. The 1914 Act was based on the English Statute, the Protection of Animals Act, 1911, ${ }^{42}$ which made an act of cruelty against an animal a criminal offence. The elements of the offence of animal cruelty includes that the accused (1) cruelly (2) ill-treats, overload etc. (3) an animal (4) with intent. ${ }^{43}$ Earlier cases ${ }^{44}$ have emphasised the fact that cruelty consists in causing unnecessary pain or suffering and in terms of proving the offence of cruelty, it is essential to allege and prove that the specific act was done cruelly. ${ }^{45}$ Judicially, cruelty has been defined as "causing unnecessary suffering" or "causing substantial pain ... not reasonably necessary in the circumstances". ${ }^{46}$ Under Section 1 of the Animals Protection Act

40 Rautenbach, "Umkhosi Ukweshwama", 86.

41 Youens K. 2001. Animal Rights: A Moral and Legal Discussion on the standing of animals in South African Law, LLM Diss, University of the Witwatersrand, 23.

42 Milton JRL and Fuller NM. 1971. South African Criminal Law and Procedure. Cape Town: Juta, 707.

43 Milton and Fuller, South African Criminal Law and Procedure, 708.

44 See, for example, $R v$ Kruger 1924 OPD 48 52; $R v$ Smit 1929 TPD 397 401; Hellberg $v$ R 1933 NPD 507510 514; $R v$ Tom 1939 OPD 23.

45 See, for example, Ex parte The Minister of Justice, In re R $v$ Masow 1940 AD 75.

46 See Milton and Fuller, South African Criminal Law and Procedure, 708, with reference to R v Hellberg 1933 NPD 507. 
No. 71 of 1962, animals protected against cruelty include any equine, bovine, sheep, goat, pig, fowl, ostrich, dog, cat or other domestic animal or bird, or any wild animal, wild bird or reptile which is in captivity or under the control of any person. This Act repealed the Prevention of Cruelty to Animals Act No. 8 of 1914 and reference is often made to cases decided in relation to similar provisions under Act No. 8 of 1914. In relation to the requirement of intent, it is essential to prove that the accused "intentionally inflicted pain or suffering" by the act of cruelty. ${ }^{47}$ The element is further described as "wilfulness" and expressed by the court in $R v$ Sibeko, ${ }^{48}$ as follows: "When ... a person without any compulsion hereto, of his own free will elects to do something, which he knows must in the ordinary way produce pain and he does that act not accidentally or under circumstances negativing intention to perform that act, then he does that act intentionally and wilfully." 49

Section 2(1) of the current Animals Protection Act sets out various actions amounting to cruelty to animals, which are prohibited and punishable with a criminal sanction. Any person who overloads, overdrives, over-rides, ill-treats, neglects, infuriates, tortures or maims or cruelly beats, kicks, goads or terrifies any animal ${ }^{50}$ or who causes unnecessary suffering through a wanton or negligent act of omission or commission ${ }^{51}$ commits an offence. A person found guilty of any such an offence can be liable on conviction to a fine or to imprisonment. The Act also provide for various other provisions dealing with cruelty to animals, including aspects relating to confinement, food supply, poisoning, health care, using on or attaching equipment equipment, appliances or vehicles, exposing animals to attacks by other animals, using unfit animals for work, trapping animals, selling devices intended for capture of animals, engaging in conveyance, carriage, confinement, securing, restraining or tethering of animals and abandonment of animals.

The Animal Protection Act further confers wide powers on societies for the prevention of cruelty to animals. These powers, in terms of the Act, include authorising any officer of such society to enter any premises where an animal is kept for the purpose of examining the conditions under which the animal is kept. No warrant is necessary if consent of the owner or occupier is obtained and if not, the officer may enter by order of a magistrate. ${ }^{52}$ The officers also have the powers of arrest and seizure. ${ }^{53}$ The Society for the Prevention of Cruelty to Animals (SPCA) is the only animal welfare organisation in South Africa regulated by an act of Parliament, namely the Societies for the Prevention of Cruelty to Animals Act No. 169 of 1993. The mission of the SPCA is to prevent cruelty and promote the

\footnotetext{
47 Milton and Fuller, South African Criminal Law and Procedure, 710.

$48 \quad R v$ Sibeko 1951 (4) SA 41 (E).

$49 R v$ Sibeko, 43.

50 Section 2(1)(a) of the Animals Protection Act No. 71 of 1972.

51 Animals Protection Act, sec 2(1)(r).

52 Animals Protection Act, sec 8(1)(a).

53 Animals Protection Act, 8(1)(b)-(d).
} 
welfare of all animals. In Society for the Prevention of Cruelty to Animals, Standerton $v \mathrm{Nel}^{54}$ the court confirmed the fact that the SPCA qualifies as an organisation that may seek an interdict in appropriate cases where harm, injury or cruelty was apprehended. In this case, the SPCA brought an application for an order interdicting the first respondent from holding a rodeo with a live bull-riding competition. The respondent argued that the SPCA's rights regarding animal welfare were narrowly circumscribed by the Animal Protection Act No. 71 of 1962 and that they had no clear right or locus standi to act beyond those powers. The Court found that there was no merit in this point and held further, that with the vast powers granted to it under the Act, it would be surprising if the applicant did not have the lesser power to prevent the injury being apprehended. The court granted the interdict.

The various animal-related laws (Animals Protection Act of 1962, Performing Animals Protection Act of 1935) empower SPCA inspectors to act on behalf of an abused animal. They are empowered to enforce the relevant legislation related to the keeping, transporting, selling and use of animals. The Inspectorate is also the law enforcement unit of the SPCA, and their inspectors have the legal power to confiscate animals, and to bring criminal charges against offenders. In Section 8 of the Animals Protection Act, it is stated that inspectors of the SPCA may enter the premises of a person or owner with the person or owner's permission, to examine the conditions under which the animals are kept. When the owner refuses to give the inspector permission to enter, the inspector has to obtain a warrant from a magistrate to enter the premises. Members of the public, who suspect that animals are mistreated, should approach their local SPCA and make a complaint. However, there are many towns and places in South Africa with no SPCA or animal welfare society. Animal cruelty is a criminal offence, and it is important that members of the public report instances of animal cruelty or animal abuse to the South African Police Service (SAPS), who should investigate any such complaint.

The Red Meat Regulations provide in Part V (Sections 64-78) for the humane treatment of animals and the slaughter process, including regulations applicable to the methods of stunning, bleeding and bleeding times. Part XI (Sections 128-130) of the regulations focuses specifically on the slaughter of animals for personal consumption and for religious and cultural purposes. Section 28 of the regulations focuses on the slaughter of animals, not in an abattoir, but in other locations, for the religious purposes of the Muslim faith. It stipulates that only a person authorised in writing by Islamic religious authorities may perform the slaughter of an animal. The regulations provide further that the slaughter must be executed in a humane manner. There is also a requirement to obtain the written permission from the local authority or a landowner of the area where such slaughtering will take place, and this applies equally to the slaughter of animals for indigenous religious or cultural purposes. In order to be permitted to perform ritual slaughter of animals in an abattoir, the person performing the slaughter must have the written authorisation of the abattoir owner and the relevant religious community must nominate him.

54 Society for the Prevention of Cruelty to Animals, Standerton v Nel 1988 (1) SA 42 (W) $44 \mathrm{H}$. 
The same requirements apply for the humane execution of the slaughter. All animals slaughtered at an abattoir must be rendered unconscious by a method of stunning in accordance with Section 73 of the regulation, before doing the bleeding incision. Methods of stunning include the captive bolt method, the electrical method or any other method approved by the provincial executive officer.

In relation to the regulation of slaughter practices on local government level, the CRL Rights Commission has recommended that municipalities look at amending bylaws to allow communities to slaughter animals for religious and cultural reasons. According to the South African Local Government Association (SALGA), municipalities accept and acknowledge the practice of ritual slaughter and according to them, it is necessary for municipalities "to review by-laws where the practice is not permitted and where it does not exist it should be developed to accommodate the practice" ${ }^{\prime 5}$ In terms of the Constitution, municipalities have legislative authority in relation to municipal abattoirs. ${ }^{56}$ The slaughtering of animals is thus typically a matter over which a municipality will have the power to make bylaws.

An example of a municipal regulation on religious slaughter is the Ekurhuleni Metropolitan Municipality Public Health Bylaw. ${ }^{57}$ The bylaw allows the slaughtering of animals, subject to the requirements of the regulation. According to the bylaw, "Ekurhuleni is not opposed to the private slaughtering of animals for ritual purposes. To do that would be an infringement on the rights of people as enshrined in the Constitution of the Republic of South Africa under the Bill of Rights. However, the exercising of these rights must be done in a way that is respectful of other people's rights as well." 58

The Ekurhuleni regulations stipulate that any person, who intends to slaughter an animal in any place other than an abattoir, must notify the relevant municipal council in writing, at least fourteen days prior to the event. A person must also obtain the written permission from the relevant landowner and may not slaughter the animal in a position where the slaughtering can be observed by any person on neighbouring premises or any member of the public. ${ }^{59}$

The CLR Rights Commission has also recommended that individuals or communities who take part in ritual slaughter practices should always obtain the necessary permission from their local authority for the planned slaughter. Municipalities should monitor that the meat is handled in a hygienic manner and that animals are treated in a humane manner at all times. However, in practice, there are often very poor communication and engagement from the side of local government with

55 Sapa. 2019. "By-laws Need to Accommodate Slaughter", News24, 29 March. In terms of Part B of Schedule 5 of the Constitution of the Republic of South Africa, 1996.

Ekurhuleni Metropolitan Municipality. 2009. “Public Health Bylaws” [Council Resolution: AET (012009) dated 23 September 2009].

Sapa. 2009. "Correct Procedures must be Followed when Slaughtering Animals", South African Government News Agency, 23 September.

99 See Ekurhuleni Metropolitan Municipality, "Public Health Bylaws", sec 125. 
communities. Communities are also ignorant of the laws, procedures and practices that are available to them in order to assert their religious rights. Local governments should appropriately and effectively engage in discussions with all affected communities before making laws or regulations.

Through the reasonable and justifiable regulation of slaughtering practices, legislation seeks to strike a balance between competing rights, provided that these laws, procedures and administrative practices are clear and generally available to those affected thereby. However, this has not been the case. Communities are in many respects ignorant of the relevant laws and applicable provisions that affect them. In other instances, they may not follow the relevant procedures outlined in the regulations, particularly in relation to slaughter practices outside of an abattoir. Local authorities find it difficult to enforce and regulate these activities, unless formal complaints have been lodged by members of the public. Public awareness and proper leadership is essential in order to create awareness of the applicable laws and to improve the proper enforcement of existing legislation. Here the CRL Rights Commission can play a crucial role. Instead of seeking to create more legislation, the Commission can assist religious communities by educating and informing them of their legal and constitutional rights and duties and creating awareness of existing laws and regulations. Section 185(1) of the Constitution states that the functions of the CRL Rights Commission are to: (a) promote respect for the rights of cultural, religious and linguistic communities; (b) promote and develop peace, friendship, humanity, tolerance and national unity amongst cultural, religious and linguistic communities, on the basis of equality, non-discrimination and free association; (c) recommend the establishment or recognition, in accordance with national legislation, of a cultural or other councils for communities in South Africa. Especially in the absence of proper processes or procedures, the Commission can play an important role. Section 185(4) emphasises the function of the Commission to monitor, investigate, research, educate, lobby, advise and report on issues concerning the rights of cultural, religious and linguistic communities. ${ }^{60} \mathrm{In}$ terms of Section 5 of the CRL Act, the Commission may also facilitate the resolution of friction between and within cultural, religious and linguistic communities, receive and deal with requests related to the rights of cultural, religious and linguistic communities, and further make recommendations to the appropriate organ of state regarding legislation that impacts the rights of cultural, religious and linguistic communities. Therefore, the Commission can also act as a mediating body when religious disputes arise and assist religious institutions and members to report religious abuses to the appropriate bodies. The Commission may also establish and maintain databases of cultural, religious and linguistic community organisations and institutions. The educational and informative role of the CRL Rights Commission can assist in creating awareness of some of the issues outlined in this discussion and promote

60 Sections 4 and 5 of the Commission for the Promotion and Protection of The Rights of Cultural, Religious and Linguistic Communities Act No. 19 of 2002 repeat these notions. 
a better understanding and compliance of the relevant laws. In its draft report, the Commission accepts this responsibility, by stating that "[a]lthough religious organizations exist as voluntary organizations; the CRL Rights Commission should provide essential assistance in helping organizations to get their house in order and to ensure compliance with existing legislation and propose new legislation." 61 The practice of religious slaughter as a manifestation of the right to freedom of religion is an important right, which also needs to be balanced against other rights, such as animal rights and the obligation to treat all animals in a humane manner.

\section{CONCLUSION}

This chapter has emphasised the importance of religious slaughter as an important component of the right to freedom of religion, but also the difficult issues in striking a balance between competing rights and interests. Although this chapter has highlighted the fact that constitutional and legislative limitations may be placed on religious rituals and practices, a court is not empowered to pronounce upon the truth or credibility of a religion. The Constitutional Court confirmed this view in a minority decision in Prince $v$ President Cape Law Society. Justice Ngcobo stated as follows:

Religion is a matter of faith and belief. The beliefs that believers hold sacred and thus central to their religious faith may strike non-believers as bizarre, illogical or irrational. Human beings may freely believe in what they cannot prove. Yet that their beliefs are bizarre, illogical or irrational to others, or are incapable of scientific proof, does not detract from the fact that these are religious beliefs for the purposes of enjoying the protection guaranteed by the right to freedom of religion. The believers should not be put to the proof of their beliefs or faith. For this reason it is undesirable for courts to enter into the debate whether a particular practice is central to a religion unless there is a genuine dispute as to the centrality of a practice. ${ }^{62}$

Section 36 analysis, in terms of the Constitution of the Republic of South Africa, has indicated that the practice of ritual slaughter can be justifiably limited through legislation and municipal bylaws. This type of regulation can be an alternative method to a total ban of the practice. A total ban on ritual slaughter would not pass constitutional muster, since Section 36 specifically requires that less restrictive means or alternative methods of regulation should be considered, in order to achieve the purpose. Support for this is also found on the European front, where Van der Schyff asserts that ... a categorical denial of the right to ritual slaughter can

61 Draft Report. 2016. "An Investigative Study of the Commercialisation of Religion in the Republic of South Africa". Study commissioned by the Commission for the Promotion and Protection of the Rights of Cultural, Religious and Linguistic Communities (August 2016), para 15.4 . 
be said to be too severe an interference with the scope of protection as it does not even allow the possibility that slaughter can be conducted in a way compatible with both religious requirements and the need to ensure that animals do not suffer more than had they been stunned. ${ }^{63}$

The reasonable regulation of ritual slaughter through legislation is a justifiable way of limiting the practice in terms of law of general application. Legislation and regulations seek to strike a balance between the humane slaughtering of animals, on the one hand, and the protection of religious beliefs, on the other, and "between society's right to a healthy environment and a religious community's right to perform ritual slaughtering" ${ }^{64}$ The preamble of the South African Charter of Religious Rights and Freedoms emphasises and recognises the fact that rights also impose the corresponding duty on everyone in society to respect the rights of others. The state must create a positive environment and respect, protect, promote and fulfil all the rights in the Bill of Rights. In exercising our various rights, everyone should aim to act lawfully and ethically in accordance with the principles of tolerance, fairness, openness and accountability. These regulations must serve as regulatory measures, but also provide guidance and information to those affected thereby. Religious communities must be able to enjoy and practise their religion in order to flourish and the state has to find an adequate balance of all needs concerned.

63 Van der Schyff, "Ritual Slaughter and Religious Freedom in a Multilevel Europe”, 97.

64 Rautenbach, "Umkhosi Ukweshwama”, 88. 